\title{
Assessment of Health Human Resources Policy for Health Workers at Community Health Centers in Eastern Indonesia
}

\author{
Nunuk Arie Suryana ${ }^{1}$, Zulfa Auliyati Agustina ${ }^{2}$ and Bintoro Wardiyanto ${ }^{3}$ \\ ${ }^{1}$ Master Program of Human Resource Development, Post Graduate school Airlangga University \\ ${ }^{2}$ Center of Research and Development for Humanities and Health Management, Indonesian Ministry of \\ Health \\ ${ }^{3}$ Master Program of Human Resource Development, Post Graduate school Airlangga University \\ Indonesia
}

\begin{abstract}
Background: The Republic of Indonesia Minister of Health Regulation No. 33 of 2015 on the Guidelines for Preparation of Health Human Resource Needs Planning addresses the procurement models of Health HR, namely the institutional model and regional model. The fulfillment of doctor needs in all regions in Indonesia, especially in Eastern Indonesia, is still a big challenge that must be faced. Method: Primary data study supported by secondary data in the form of regulations. The study design is descriptive with the data collected in the form of qualitative data (policy norms) that produced output in the form of a policy in brief. Results: The management of the Health Office and management of community health centers was not good and was not integrated. The Health Office did not involve community health centers in determining the number of community health centers staff, there was no unity in perception between the head of the Office and the head of administration along the head of staff on how to plan the staff, there was less collaboration between the head of community health centers and community health centers head of administration health and in determining the planning of placement of officers at community health centers. This is one of the causes of imbalanced distribution of community health centers because human resource management and HR planning are activities that must be carried out in an integrated manner within an organization. Conclusion: There are four compilation methods that can be used, namely Health Need Method, Health Service Demand, Health Service Target Method, and Ratios Method. Suggestion: There is a need to prioritize the fulfillment of HR needs in accordance with the needs of community health centers, especially community health centers in difficult areas.
\end{abstract}

Key Words: Health Human Resources, Health Workers, Community Health Centers.

\section{INTRODUCTION}

Health Human Resource is one of the national health subsystems, which has a close relationship with service units. The fulfillment of doctor needs in all regions in Indonesia, especially in Eastern Indonesia, is still a big challenge that must be faced. In the distribution of doctors, some regions experienced difficulties even though basically Health HR needs planning has been arranged. In 2015, 9,731 community health centers had 17,760 general practitioners with a shortage of 2,594 people and 6,809 dentists with a shortage of 4,603 people (Source of the PPSD Health Agency 31 December 2014). It was also stated that the lowest ratios were present in West Sulawesi (8.8/100 thousand), NTT (10/100 thousand), Maluku (12.5/100 thousand), North Maluku (12.6/100 thousand) and NTB ( 13.6/100 thousand) (Ministry of Health Data for 2012-East Indonesia Lacking Doctors).

Community health centers are the spearhead of the first level healthcare provider. Community health centers are responsible for health problems in its working area. There are three main functions of community health centers, namely (1) a center for driving health-oriented development, (2) a center for community empowerment in the health sector, and (3) a basic service center. Based on the functions and tasks of community health centers, the fulfillment of doctors is a special priority that must be put as a concern. Overall, Indonesia is still experiencing a shortage of health workers, as well as an unbalanced distribution between one city and another city and one village with another village within the same city. The definition of health personnel contained in 
article 1 of Law no. 36 of 2014 is "... everyone who devotes himself in the health sector and has knowledge and/or skills through education in the health sector which for certain types requires the authority to make health efforts... "

Existing health workers tend to work in areas that have strong economic capacity with a high population density, while regions with low economic capacity and few residents attract less interest from prospective workers. In relation to the health financing system, the existence of health workers is the main requirement so that the health financing mechanism can run perfectly, thereby increasing access to services. The policy on the distribution of health personnel developed by the Ministry of Health is welcomed by various stakeholders, but there are still some notes that form the basis for future policy improvements. The policy regarding non-permanent doctors working in the short term is not in line with programs developed by professional associations, especially those related to continuing professional development. In terms of employment opportunities, the presence of health workers in the short term does not allow them to get opportunities to work effectively. Policies regarding the distribution of health workers are dynamic and contextual. Thus, several policies that have been issued need to be reviewed in relation to their impact on the ground.

\section{MODEL}

\section{Conceptual framework}

Input

Process

UU No 23 Th 2004

PP 38 Th 2007

PerMenKes No 33 Th 2015

PerMenKes No 16 Th 2017

SK MenKes No 81 Th 2004

SK MenKes No 75 Th 2014

SK Bersama Mendagri,

MenPan,Menkes No 61/2014, No

68/2014, No 08/SKB-RB/2014

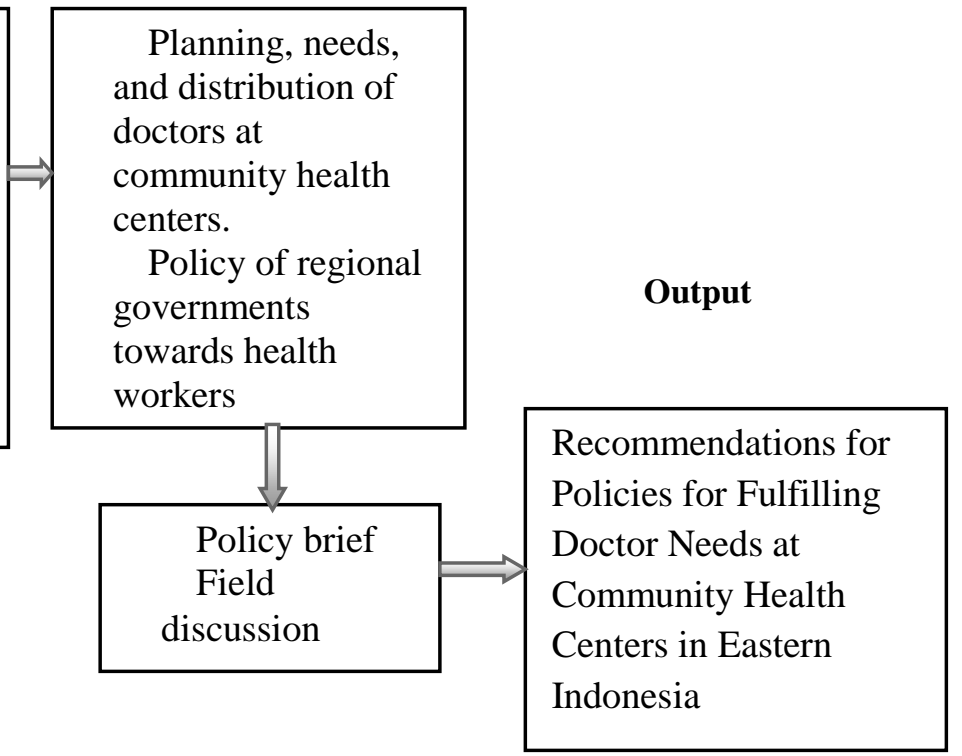

Figure 1. Conceptual framework

This study used a qualitative descriptive method, and the analysis was simultaneously carried out so that a draft policy was obtained, which was compiled according to the rules of policy-making. This research was conducted by field confirmation in Malang Regency and Sumenep Regency for 4 months, namely September-December 2017. The reason for choosing the regions for confirmation of the findings is the level of conformity with the Eastern Regions of Indonesia. Primary data were obtained through in-depth interviews, supported by secondary data in the form of regulations. Secondary data were data obtained from library studies or official networks about planning, needs, and distribution of doctors at community health centers in Indonesia and abroad. The analysis was carried out by collecting materials in the form of legislation and discussions, followed by field confirmation with policy makers in the area.

\section{RESULTS}

One of the main objectives of the 2015-2019 RPJMN is the fulfillment of the needs of health personnel, drugs, and vaccines, which of course is intended to improve access and quality of basic and referral health services, especially in remote, disadvantaged, and border areas (Rentra-KemKes 2015-2019). Although the development of health efforts has increased, there are still several problems, including that: a) there are still disparities in terms of geography, fiscal capacity, regional expenditure, education, infrastructure, access and health service facilities, overlapping targets for poverty reduction, and access to public facilities (sources of Health Facility Research 2011 and other sources); b) access to households that can reach healthcare facilities and the number of healthcare facilities in remote, disadvantaged, and border areas, as well as outermost and outlying small islands, is still low. The long distance of healthcare facilities is accompanied by uneven distribution of health workers, including the availability of doctors, which is the highest at community health centers in Yogyakarta Province with 100\% and the lowest in Papua Province with 68\%, and expensive health services which cause low accessibility to health services. 
Health policy planning and human resource programs are still weak and have not been supported by the availability of an information system related to adequate health human resources; c) there is still a lack of harmony between the needs and provision of various types of health human resources, the quality of the results of health human resources education, and uneven quality of health training in general (Ministry of Health Strategic Plan 2015-2019). According to the Ministry of Health's Strategic Plan for 2015-2019, the fulfillment of health human resources needs is still inadequate, especially in the distribution of health workers, which is still uneven. The ratio of doctors in Indonesia is 19 doctors per 100,000 population. This number is still low when compared to other countries in ASEAN, such as the Philippines with 58 doctors per 100,000 population and Malaysia with 70 doctors per 100,000 residents in 2007. Data from the Ministry of Health shows that the number of health human resources in 2012 was 707,234 people and increased to 877,088 people in 2013. Of all available health human resources, around $40 \%$ work at community health centers. The number of health workers is quite large, but the distribution is not even. Some health workers who work at community health centers are medical personnel (9.37 people per community health centers).

Health services in hospitals still face obstacles in the form of a shortage of health workers at the hospital. In 2013, there was a shortage of $29 \%$ of pediatricians, $27 \%$ of obstetricians, $32 \%$ of surgeons, and $33 \%$ of internists. Some community health centers do not have doctors, especially those in remote areas. Every year, there are around 2,500 new doctors. General practitioners who have STR numbered 88,309 people, so the ratio of general practitioners is 3.61 doctors per 10,000 residents. According to WHO recommendations, the ideal ratio is 10 general practitioners per 10,000 residents. The percentage of doctors who passed the competency test was $71.3 \%$ for doctors and $76 \%$ for dentists.

The management of the Health Office and community health centers was not good and was not integrated. The Health Office did not involve community health centers in determining the number of community health centers staff. There was no similarity in perception between the head of the Office and the head of the administration and the head of staff affairs on how to plan the personnel. There was a lack of collaboration between the head of community health centers and the head of community health centers administration/staff affairs sections in reporting the labor requirements to the health office and in determining the planning of placement of officers at community health centers. This is one of the causes of uneven distribution of community health centers because human resource management and HR planning are activities that must be carried out in an integrated manner within an organization.

From the results of field clarification in Sumenep Regency, Sumenep Regency is a Regency located in the Madura Islands on the east end with an area of 2,093.457573 $\mathrm{km}^{2}$ with a population of 1,081,204 people in 2017. Geographically, Sumenep Regency consists of 126 islands, namely 48 inhabited islands, 78 uninhabited islands, 104 named islands, and 22 unnamed islands. Administratively, Sumenep Regency consists of 17 Mainland Districts and 9 Islands Districts, namely Giligenting, Talango, Nonggunong, Gayam, Ra'as, Sapeken, Arjasa, Kangayan, and Masalembu. The distance between islands is quite far, which can be seen from the distance between Kalianget in Sumenep mainland to other islands as follows: Kalianget-Sepudi Island are 27 nautical miles apart; Kalianget-Ra'as Island are 40 nautical miles apart; Kalianget-Kangean Island are 88 nautical miles apart; Kalianget - Sapeken Island are 123 nautical miles apart; Kalianget-Masalembu Island are 114 nautical miles apart ; KaliangetKaramean Island are 151 nautical miles apart (including Masalembu sub-district); Kalianget-Sakala Island are 165 nautical miles apart (including Sapeken District). Of the 9 island chains, there are 8 general practitioners in the populated archipelago area.

The statement of the Secretary of the Sumenep Health Office regarding planning of doctors is as follows:

"Planning for the needs of general practitioners and dentists at community health centers has been carried out by a team of planners from the Health Office, who have not explicitly used certain methods. Planning is carried out based on community needs for the presence of doctors by considering a) population, b) morbidity rates in the area, c) distance/access to healthcare facilities. Planning is carried out by estimating the number of general practitioners and dentists needed based on proposals from community health centers The Health Office acts as an intermediary for the proposals because those who have the authority to recruit health workers, especially general practitioners and dentists, are the Regional Civil Service Agency (hereinafter abbreviated as BKD). The authority of the BKD is inseparable from the availability of the budget provided by the Central/Regional Government "

According to the Regional Civil Service Agency of Sumenep Regency:

"Considering that the need for medical personnel is very urgent, especially in the archipelago community health centers which must have doctors, also complying to the Minister of Health Decree No. 75 of 2014 on community health centers and preparation for community health centers accreditation, the fulfillment of doctors in the archipelago no longer uses the WISN method, but the planning still uses the WIS method ".

Marlinda (2011) in a research titled "Analysis of planning systems for the needs of health workers at community health centers in the working area of the Mentawai Islands District Health Office" concluded that the planning system had not gone well due to lack of available data and inaccurate data, lack of socialization and information about policies used in planning health workers, and lack of consultation and coordination. The results of Lukman and Christian's research entitled "Distribution of Personnel in 
Aceh Besar" stated that the analysis of workforce planning has not been carried out in health centers so that the impact of public health services is not optimal and officers are concentrated in urban areas. The health office did not involve community health centers in determining the number of community health centers staff, there was no similarity in perception between the head of the Office, and the head of the administration, and the head of staff on how to plan the personnel. In the distribution of labor, the Health Office always prioritizes remote areas that lacked personnel, but finally the decree remained the sole authority of the Regional Government (Pemda). The health office was forced to accept personnel who had been determined through Decree by the Regional Government, even though in reality the decree made by the Regional Government was no longer in line with the prior proposal from the Health Office.

The Australian Graduate School of Management conducted research on 541 organizations. The result was that only $37 \%$ had an HR planning system based on scientific analysis and $41 \%$ did not have a good HR planning system, and the remaining $12 \%$ had no HR planning at all. The results of this study illustrated that even in developed countries only a third of organizations have an HR planning system, while a majority of $63 \%$ had not yet carried out the HR planning function, which ultimately yielded an effect in the form of the low quality of performance and productivity. (Stone, 1995 in Ilyas, 2004).

Research Results from the East Java Provincial Health Office with the Indonesia Partnership for Health Systems Strengthening (AIPHSS) entitled "Labor Distribution Health Policy to Improve Access to Health Services" concluded that, first, revisions to existing policies need to be made. The policy also needs to be supplemented with guidelines and tools to assist relevant planning units and stakeholders at each level of government administration. In addition, in order to ensure optimal distribution of health workers, bottom-up planning' requirements need to be encouraged and implemented. Second, the effective distribution of health workforce cannot solely be assessed by the ratio of health workers and the population served. This is especially so in areas with large geographical areas with low population densities. The ratio may not reflect the true condition of access to health services. Third, at every level of government administration, the bottom-up planning process must be promoted and strengthened.

The Research by the Development Planning Agency in 2005 on the Health Workforce Planning Policy Study concluded that problems could arise if the placement was not in accordance with the proposal, due to a lack of coordination between the Health Office and BKD. The results of Yasin Ilyas' writing in the VOLUME 09 of Health Services Management Journal, No. September 3, 2006 Pages 146-155 concluded that the determinants of the distribution of specialists in the cities/regencies that are significant are: high per capita GRDP; low number of infant deaths, and high population density. 2. Specialists prefer to work and live in urban areas. 3.A comprehensive management intervention needs to be developed to distribute specialist doctors to hospitals in all regencies of Indonesia.

The research by Paulo Ferrinho1, Seter Siziya, Fastone Goma, and Gilles Dussault on the human resource for health situation in Zambia: deficit and distribution concluded that workable solutions were to redistribute tasks among teams of health workers through wider delegations (task-shifting), new task shifting and creation strategies so that those who will be transferred or shared must be negotiated and decided locally in the context of the policy, which aims to improve access to health services and to reduce unmet needs.

From the above opinions, it can be stated that the planning of health workers should be in accordance with the needs of the region and the condition of the existence of health facilities and submitted to the Regency/City and Province. Furthermore, it is explained in Article 1 paragraph (2) of the Joint Regulation of the Minister of Health of the Republic of Indonesia, and Regulation of the Minister of State Apparatus and Bureaucratic Reform of the Republic of Indonesia Number 61 of 2014 , Number 68 of 2014, and Number 08/Skb/Menpan-Rb/10/2014 that the Distribution Health Workers is the process of structuring the placement of health workers so that the number, type, and quality/qualifications of health workers are in accordance with the real needs of each health service facility, and Article 5 states the Types and Number of Health Workers as referred to in Article 4 letters (a) and (b) are subject to the needs of health services and the availability of Health Service Facilities belonging to the Regional Government. Furthermore, Article 11 states that in the event that the implementation of redistribution as referred to in Article 10 has not been able to meet the needs of Health Workers, the Minister of Health may distribute it to provinces and regencies/cities that lack Health Workers in all regions of Indonesia in accordance with the legal provisions. This is affirmed in Article 14 paragraph 2 of the Law on Health Workers that Health Workforce Planning is structured in stages (starting from Health Service Facilities, Regency/City Government, Provincial Government, up to the national Government) based on the availability of Health Workers and development implementation needs and Health Efforts.

\section{DISCUSSION}

\subsection{The planning for the needs of doctors at community health centers is based on the regional concept}

The planning of health workers needs to prioritize energy needs to realize proactive preventive and promotive efforts, without ignoring curative and rehabilitative efforts (Ministry of Health, 2004). The planning of health workers needs to pay close attention 
to the needs of the right composition of various types of health workers in the future that are needed by the community (Ministry of Health, 2000). In an effort to implement it, the plan covers the number, type, and quality, as well as fair and even distribution, according to the demands of health development needs without discriminating between the regions.

According to the National Health System (SKN), health resource planning is,

1. The preparation of health human resource needs plans is carried out by taking into account the priority needs of health human resources, both in primary health efforts and secondary and tertiary health efforts.

2. Health human resource planning which includes the type, number, and qualifications is carried out by enhancing and strengthening its relationship with other elements in the management of the development and empowerment of health human resources by taking into account health development goals and trends in health problems in the future.

3. Health human resource planning is carried out based on facts (evidence based) through the improvement of health human resource information systems.

Law No. 36 of 2009 on Health stipulates that the government regulates planning, procurement, and utilization, as well as fostering and supervising the quality of health workers in the context of administering health services. The Ministry of Health 2010-2014 Strategic Plan stipulated by the Decree of the Minister of Health of the Republic of Indonesia Number 021/MENKES/SK/1/2011 was updated with Ministry of Health Decree Number 32/Menkes/SK/1/2013, which states that one of the Ministry of Health's missions is to ensure availability and equitable distribution of health resources. The availability and equal distribution of health resources includes health workers who are sufficient in number, type, and quality, as well as being effectively distributed in accordance with the interests of the community fairly, especially in the Disadvantaged, Border, and Archipelago Areas (DTPK) and health problem areas. (Anonymous, 2013)

The Decree of the Minister of Health of the Republic of Indonesia No. 81/Menkes/SK/I/2004 on Guidelines for Preparation of Health HR Planning at Provincial, Regency/City, and Hospital Levels states that the method used in calculating energy requirements is the Workload Indicator Staff Need method (hereinafter abbreviated as WISN). The WISN method is a method of calculating health HR needs based on the real workload carried out in each category of health human resources in each work unit in healthcare facilities. In the WISN method, there are five steps, namely: establishing available work time, assigning work units and HR categories, compiling workload standards, compiling allowance standards, and calculating the labor requirements per work unit (MOH, 2004). These steps describe each doctor's activities, which include administrative functions and medical functions. This method is comprehensive, realistic, and easy to implement. This method requires accuracy because if an error occurs in one step, it will produce effects on subsequent calculations, in addition to that the data must be valid.

\subsection{Policy of the Government and Regional Government on the Fulfillment of Doctors at community health centers}

Health workers have an important role to improve the quality of health services to the community so that the community is able to increase awareness, willingness, and ability to live healthy, so that the highest degree of health will be realized as an investment for the development of productive human resources. The WHO in 2010 advocated various models of the distribution of health workers to rural areas so that they can be applied to overcome the problem of distribution of health workers. The recommendations were developed based on various inputs and evidence obtained from various countries that experienced a maldistribution of health workers. Various models in the distribution of health workers have been developed, but there are still problems that some community health centers had not been populated with doctors.

Regulation of the Minister of Health number 75 of 2014 requires that community health centers must have at least two doctors. However, to fulfill the Minister of Health Regulation, there are classic problems, namely limited formation of doctors and regional finances in providing employee salaries. As an effort to fulfill doctors in the regions, of course the role of regional heads is a key element in addition to the role of the central government. The results of the field study in Sumenep Regency showed that the Government's role in fulfilling doctors at the islands community health centers was carried out by increasing expenditure from regional income to pay salaries and incentives for doctors at community health centers on the islands.

According to the Secretary of the Sumenep Regency Health Office:

"From the results of the energy needs planning, which subsequently is mapping the placement of workers, as well as community accessibility to the existence of health service facilities and fulfilling the Minister of Health Regulation Number 46 of 2015 concerning community health centers Accreditation, the Sumenep Regency Government decided that the island regions require doctors. Based on a joint meeting between the Head of Sumenep Regency, Budget Planner of the Regional Government of Sumenep Regency, Regional Civil Service Agency, Sumenep Regency House of Representative, and Sumenep Regency Health Office, it was decided that the Regency was to comply to Minister of Health Regulation no. 75 of 2014 and Minister of Health Regulation no. 46 of 2015 on salaries and incentives through the Budget Work Plan at the Sumenep Regency Health Office ". 


\subsection{Support from the Government and Regional Government in fulfilling doctors at community health centers}

In the context of the placement of health workers in the interests of public services and equity, the Government/Regional Government carries out various arrangements to provide material or non-material benefits to health workers in providing health services in areas that do not attract interest, such as remote areas, very remote areas, disadvantaged areas, border areas, outermost and outlying islands, and disaster areas and conflict-prone areas. Eastern Indonesia. One element that plays a role in accelerating health development and is included into the main target of health development in the 2015-2019 RPJMN is the fulfillment of health workers who are assigned to health service facilities in the community. The number of health workers in health facilities has a major role in the promotive-preventive sector, but in reality the types and proportions of workers are still dominated in curative and rehabilitative fields. This is due to the limitations of the number and types of workers.

From the results of the field confirmation in Sumenep Regency. According to the Head of Finance Section of the Sumenep Regency Health Office:

"Basically the doctors placed at the Archipelago Community Health Centers are selected staff who are in charge of serving the community with salaries received in accordance with the Sumenep Regency minimum wage, which is between Rp.2,300,000 up to Rp.2,500,000 per person, added with an incentive of Rp.2,500,000,- charged to the Regional Government budget through the Sumenep Regency Health Office Budget Work Plan, along with supervision and guidance."

The East Java Provincial Office with the Australia Indonesia Partnership for Health Systems Strengthening (AIPHSS) in the "Health Workforce Distribution Policy to Improve Access to Health Services" stated that the support that must be given to doctors devoted to rural areas needs to pay attention to adequate facilities and infrastructure for its working area and building adequate infrastructure so that access to health for the area is not left behind by already developed regions. For these areas, the rewards offered must be large so that the area has the attraction to foster the careers of health workers, which guarantees the future life of these health workers.

\section{CONCLUSION AND SUGGESTIONS}

\subsection{Conclusion}

The planning of health worker needs have four compilation methods that can be used. The first is Health Need Method, which is planning of health worker needs based on the main epidemiology of diseases that exist in society. The second is the Health Service Demand, which is the planning of health worker needs based on demand due to the burden of health services. The third is the Health Service Target Method, which is the planning of health worker needs based on defined health service facilities, such as community health centers and hospitals. The last is the Ratios Method, which is the planning of health workers needs based on standards/ratios toward certain values. The results of field studies and several theories obtained illustrated that the planning of doctors at community health centers was based on a) Regional needs, b) morbidity rates (evidence base), c) access to health facilities, and d) wide geographical area with high population density. Personnel planning is arranged in stages, namely by the Regency/City Health Service with the Regional Civil Service Agency, as well as the Province. Government and Regional Government policies in the preparation of doctor personnel planning at community health centers are the Regulation of the Minister of Health number 75 of 2014 requiring that community health centers must have at least two doctors and Regulation of the Minister of Health Number 46 of 2015 concerning community health centers Accreditation, Law Number 36 Year 2014 concerning Health Workers in article 6, article 7, article 13, Article 23, and article 29. The support of the Government and the Regional Government in fulfilling the needs for doctors at community health centers is in the form of provision of incentives and salaries, adequate facilities and infrastructure for their working areas, and the construction of adequate infrastructure so that access to health for these regions is not left behind from developed regions, as well as training and retraining, including shifting tasks, which are done as often as possible. Studies on the Fulfillment of Health Workers in Indonesia have been carried out by various academics and policy makers, as well as policies in the form of legislation, Ministry of Health Regulations, and joint regulations between the Minister of Health, Minister of Home Affairs, and Minister of State Apparatus and Bureaucratic Reform. However, these policies cannot be implemented in several regions, considering that each region has different specifications. Regulations that are issued universally are still not specific, reflecting geographical conditions that are difficult to reach. The Minister of Health Regulation No. 75 of 2014 on community health centers only mentions the number of doctors in community health centers and Regulation of the Minister of Health Number 46 of 2015 on community health centers Accreditation were made as if only for the fulfillment of obligations to the Social Security Organizing Agency (BPJS), namely as a requirement for the cooperation with BPJS. The Ministry of Health has provided assistance in calculating the needs of health workers using the workload method (WISN), but the guidelines are not appropriate if implemented in Eastern Indonesia because the population and service facilities 
are limited, besides the health workers not properly understanding the functions of community health centers, so the existing workload seemed very low.

\subsection{Suggestions}

Several laws and regulations, policies on planning for the fulfillment of health workers and distribution of energy as a basis for adequate public health services have been issued, but there are still many findings that healthcare facilities are not equipped with doctors. This happened in the Eastern Indonesia Region, as data from the Health Human Resources Development and Empowerment Agency (27 February 2017) showed that for Eastern Indonesia, from the specified target of 45 doctors per 100,000 population, the current condition was an average of 26 doctors per 100,000 residents, far from the WHO-determined target. This condition occurred because planning has not been facilitated properly. The Government and the Regional Government have the authority to fulfill the medical personnel (Law Number 36 of 2009 concerning Health). The Governor and Regent have the authority in the planning and redistribution ofhealth workers (Joint Regulation of the Minister of Health of the Republic of Indonesia, Minister of Home Affairs of the Republic of Indonesia, and Minister of State Apparatus and Bureaucratic Reform of the Republic of Indonesia Number 61 of 2014, Number 68 of 2014, and Number 08/Skb/Menpan-Rb/10/2014 concerning Guidelines for Preparation of Health Human Resource Needs Planning), but in its implementation there are still problems. From the results of the study, the fulfillment of doctors at Eastern Region Indonesia community health centers should pay attention to:

1. Geographic conditions, which include mountains, islands, and borders

2. Availability of facilities and infrastructure for health service facilities

3. Level of regional needs by considering:

a) level of population density;

b) local epidemiology based on evidence base;

c) availability of regional budgets as an effort to provide incentives;

d) adequacy of area in meeting healthcare facilities in cases when they are far from the referral locations (island ambulances);

4. Satellite community health centers as archipelago cluster community health centers;

5. Opportunities in the development of doctors' education and careers;

6. Development of telemedicine and teleconference for Sister Hospitals

\section{REFERENCE}

[1] Andreasta Meliala, Ian Anderson, 2014, The production, distribution, and performance of physicians, nurses, and midwives in indonesia: an update. Health, Nutrition, and Population (HNP) Discussion Paper,Worldbank.org,http://documents.worldbank.org/curated/en/912471468254690409/pdf/913240WP0UHC0C00Box 385331B00PUBLIC0.pdf

[2] Barber SL1, Gertler PJ, Harimurti P, 2007 The contribution of human resources for health to the quality of care in Indonesia, Health Aff (Millwood) May-Jun;26(3):w367-79.

[3] Carmen Dolea, Laura Stormonta \& Jean-Marc Braicheta, 2010, Evaluated strategies to increase attraction and retention of health workers in remote and rural areas (Bulletin of the World Health Organization 2010;88:379-385. doi: 10.2471/BLT.09.070607,

[4] Gilles Dussault and Maria Cristina Franceschini, 2006, Not enough there, too many here: understanding geographical imbalances in the distribution of the health workforce, Human Resources for Health, Published: 27 May 2006, doi: 10.1186/1478-4491-4-12

[5] Hendro Nurcahyo, Antono Suryoputro, Sutopo Patria Jati, Analisis Proses Rekrutmen Dan Seleksi Tenaga Kesehatan Tim Nusantara Sehat Dalam Program Nusantara Sehat Kementerian Kesehatan Republik Indonesia. Jurnal Kesehatan Masyarakat (e-Journal) Volume 4, Nomor 4, Oktober 2016 (Issn: 2356-3346) Http://EjournalS1.Undip.Ac.Id/Index.Php/Jkm

[6] Yaslis Ilyas ,2006, Determinan Distribusi Dokter Spesialis Di Kota/Kabupaten Indonesia Determinant Factors Of Doctor's Distribution In City/District Jurnal Manajemen Pelayanan Kesehatan Volume 09, No. 03 September 2006 Halaman 146 - 155,

[7] Liudvika Starkiené, 2013, Inequitable geographic distribution of physicians: systematic review of international experience., Health Policy and Management, Researh Journal Vol 1 No 5 
[8] Michael A Munga and Ottar Mæstad,2009, Measuring inequalities in the distribution of health workers: the case of Tanzania., Human Resources for Health 7:4 doi:10.1186/1478-4491-7-4,

[9] Michael A Munga, Nils Gunnar Songstad, Astrid Blystad and Ottar Mæstad4, 2009, The decentralisation-centralisation dilemma: recruitment and distribution of health workers in remote districts of Tanzania., BMC International Health and Human Rights Published: 30 April 2009 doi:10.1186/1472-698X-9-9,

[10] Paulo Ferrinho1, Seter Siziya, Fastone Goma and Gilles Dussault1, Ferrinho, The human resource for health situation in Zambia: deficit and maldistribution. , Journal Human Resources for Health 2011, 9:30,

[11] Suwit Wibulpolprasert,2003, Integrated Strategies To Tackle The Inequitable Distribution Of Doctors In Thailand, Hum Resour Health. 2003; 1: 12. doi: 10.1186/1478-4491-1-12 